\title{
SUSTAINING SOCIAL DISCOURSE THROUGH SCREEN VERSIONS OF LITERARY WORKS IN TEACHING THE SECOND FOREIGN LANGUAGE
}

\author{
Assoc. Prof. Dr. Dileta Jatautaitė, Assoc. Prof. Dr. Jelena Kazimianec
}

General Jonas Žemaitis Military Academy of Lithuania

\begin{abstract}
In the article, with reference to the screening of M. Bulgakov's play Ivan Vasilievich, the feasibility of utilizing film-intertexts in a foreign language course particularly in Russian classes for foreign learners - is corroborated, and the principles of selecting them for educational purposes are determined. Screen versions of literary works are viewed as a means of familiarizing foreign students with this book. Furthermore, social discourse (from Latin discursus means "running to and from", Compact Oxford Dictionary, Thesaurus and Wordpower Guide (2001) denotes written and spoken communications in semantics and discourse analysis. The authors of the article scrutinize L. I. Gaidai's fiction film Ivan Vasilievich Changes Profession (1973), a screen version of Mikhail Bulgakov's play, in regard as a film-intertext. Moreover, the authors present a great number of linguistic and cultural resources which are considered as precedential video texts. Herein, discourse serves also as a conceptual generalization of a discourse within each modality and context of communication. Sustainability of social discourse pays an indisputably significant role in the society, and its impact and genesis have long been a distinctive research object of social sciences in order to bring original discourse into the language-learning classroom which becomes a special type of discourse community in which teachers and students ideally become reflective researchers of historical evolution of the target language. Sustainability of social discourse via screen versions of literary works has become a dominant method used in the classes of foreign language teaching for it is a perfect reflection of a social language change in the public sphere and ubiquitous ideal of social change.
\end{abstract}

Keywords: screen version, cinematographic, M. Bulgakov, film-intertext, foreigner, cultural and language resource.

Introduction. With the lack of speaking environment - wherein the learner may apply the knowledge gained during language classes and interact naturally learning a foreign language has remained an urgent issue of linguadidactics by foregrounding the need to recreate artificially the conditions of real communication in the target language so that to ease the gap between artificial use of language in the classroom by non-native speakers and genuine or communicative use by native language users. By technologizing and computerizing all the spheres of social 
activities, as well as developing an individual's sustainable skills of perceiving information through a screen version of a literature work on television, it has become obligatory to create teaching aids encompassing the audio-visual aspect as a substantial element of teaching and learning material of a second foreign language at any level of learning. Such an approach makes the learning of an individual be oriented towards real life situations. In this regard, methodically developed materials of a film version of a literary work can become an integral part of a foreign language course and can be used as irreplaceable teaching sources enabling learners to be immersed into the realm of actual and real communication discourse in the target language. M. Foucault (1969) describes discourse as "an entity of sequences, of signs, in that they are enouncements (énoncés)", statements in conversation.

Thanks to screen versions, in this case of Russian literature, the learners are acquainted with language structures and vocabulary necessary to communicate in a second foreign language, for instance, Russian. Moreover, it helps them better comprehend social and cultural aspects of realities such as Russian literature, history, traditions, and customs, and acquire the peculiarities of Russians' speech functions; learn to understand body language, facial expressions, gestures, and apprehend that a film-intertext being a finished product of spoken or written communication discourse is an idiosyncratic text wherein visual and auditory images, verbal and non-verbal means of information transfer which are harmoniously intertwined. Additionally, a communicative situation is represented in its full capacity as close as possible to real life situations.

The object of the research - sustaining social discourse through the screen version of a literary work in teaching the second foreign language.

The aim of the research is to sustain social discourse through the screen version of a literary work in teaching the second foreign language.

The following objectives were set through:

1. Developing language competence in the domains of phonetics, lexis, and grammar;

2. Developing skills in the various types of speech activity, that is, communicative competence: listening, speaking, reading, and writing;

3. Developing linguistic and cultural competence;

4. Developing social and cultural competence; that is, understanding both the rules of verbal and non-verbal behavior in typical communicative situations and the peculiarities of Russian native speakers' etiquette, and being able to coordinate behavior in accordance with this understanding;

5. Familiarizing with A. Bulgakov's oeuvre and short literary analysis of his work. Methodology and methods of the research. Sustainability of social discourse has become an establishment of a cultural form of life that deepens, shapes everyday practices, and self-relations of the learners who study foreign languages. Hence, thanks to audio visual method and telecinematic, teachers evaluate and rethink the language approach, attitudes, and methods of presentations in the 
classroom. In return, the learners in this situation are supposed to use and apply metacognitive strategies and self-evaluation in order to improve their language performance through sustaining social discourse on the basis of screen versions of literary works. Subsequently, this concept of language teaching and learning approach gained great interest among the teachers and didactics scholars. Meadows (1972) and Beck (1992) in their Report for the Club of Rome in the 1970s claimed that it was used as a reaction to potential crisis and global risks that started forming new general awareness of an individual at the final quarter of the twentieth century (Meadows, 1972; Beck, 1992). Sustainability of social discourse via screen versions of literary works has become a dominant method used in the classes of foreign language teaching for it is a perfect reflection of a social language change in the public sphere and ubiquitous ideal of social change. Henceforth, it was also a natural reaction to enormous and uncontrolled usage and accessibility of cinematography, television, computers, and lots of other audio and visual technologies in all spheres of life. In Brundtland Commission's Report, sustainability was presented as follows: "Sustainable development that seeks to meet the needs and aspirations of the present without compromising the ability to meet those of the future" (WCED 1987, CH.1, POINT 49). Thus, for this reason it has become absolutely evident and estimated necessity to start implementing a screen version of literary works into the teaching and learning process of the second foreign language by employing metacognitive strategies and self-evaluation of a learner by developing and sustaining his or her social discourse of the second foreign language.

The didactics scholars, who support the advantages of sustaining a social discourse of a screen version of a literary work in the language classroom, tend to focus on the proximity of the scenes depicted with everyday situations (McDonough, Show, 1993) or acquisition of linguistic competences related to "contextual, paralinguistic and extralinguistic elements" (Rossi, 2006). Moreover, Murdoch (1999) in his works claims telecinematic method or a screen version of a literature work as a suitable language teaching material and technique for developing and sustaining foreign language learning discourse. Moreover, films can extend the learning beyond the textbook especially by helping students get awareness of a particular era or an event that reflect the certain historical language discourse and its context. Films, therefore, provide the learner with a great number of utterances that have been validated by native speakers. This comes in handy in quest of sustaining good foreign language discourse when easy-to-share examples open "narrow theories" by documenting the existence of a specific language usage. For example, Bolinger (1989) states that films record a number of speech segments, which reveal a functional rather than a strictly syntactic approach to English tags, etc. Therefore, not all films based on literature works, however, are suitable for educational purposes. The choice of suitable film-related materials is undoubtedly the most significant and complicated stage of preparation for a lesson. Furthermore, it also a very time-consuming task for a specialist to select an appropriate storyline for sustaining a qualitative discourse 
use in the classroom. For example, the Common Core State Standards (CCSS) for English Language Arts can be handy for a teacher in helping to identify a film as a qualitative text (in teaching English). Also, there are specific standards for the use of films, for example, by comparing and contrasting texts. Additionally, they establish guidelines for English Language Arts (ELA) as well as for literacy in history/social studies, science, and technical subjects. ELA state (Common Core State Standards Initiative, 2020): "analyze the extent to which a filmed or live production of a story or drama stays faithful to or departs from the text or script, evaluating the choices made by the director or actors." Hence, a screen version of literary works provide a perfect setting for foreign language learners to endeavor into the professional world and language discourse in an appropriate virtual and natural setting (Jatautaite, Kazimianec, 2018). Since the learner's engagement is a priority for a successful learning and acquisition, the learners are taught to experience the pleasure of learning (Richards, Rodgers, 2001) through authentic cinematographic language material. This linguistic material, for example, is a totality codified in a particular given field of intellectual study and social practice.

Depending on specific social discourse shapes and dynamic forces, they mutually influence each other (Weingart, 2002). For example, the sincerity of actors presenting the arguments and the positional suitability of the content and goals mediated in discourse, i.e. how far they reinforce or linger personal positions. If and how specific social discourses are adopted and get effective depend on various factors (Conrad, 2012; Hajaer, 1995):

1. The (changeable) social relevance of the discourse theme.

2. The pattern of interest of the actors organizing the discourse.

3. The (subsystem-specific) communicative connectivness of the discourse.

4. Its resonance ability in other social subsystems. This, therefore, is powerfully resoluted by framings and storylines affecting the discourse.

\section{The Screen Versions of the Well-known Literary Works in Sustaining Social Discourse}

Among the films which could be characterized as highly valuable teaching aids, the texts accentuating the screen versions of the well-known literary works which interrelationship with, herein, Russian literature makes these film-related texts very attractive for both teachers and learners. During the communication and sustainability of discourse, being realized through film-intertexts, a constant reference to the precedents from works of literature is a necessary precondition for foreign learners to be familiar with them.

Considering a plethora of precedential texts, one should distinguish first those literary works which are incorporated into the curriculum. They are typical of cultural background of an "average", herein, Russian native speaker; therefore, their predominance among precedential texts is unequivocally understandable. A 
native speaker regularly appeals to the following literary works: a) folk literature, that is, nursery fairy tales (Cinderella, Sleeping Beauty, Roly-Poly, etc.), folk tales, anecdotes; b) domestic and foreign classics (it is the Russian classics' literary works that Russian native speakers treat as precedential texts); c) lyrics of Russian songs; d) children's literature [7: pp. 62-63]. To this list, it is necessary that texts should be excerpted from famous and loved films. Therefore, people of the twenty-first century appear to refer more often exactly to the texts in films and their images. Loved by Russian viewers and known to an overwhelming majority of the Russian linguacultural community, the films incorporating abundant linguistic and cultural resources may be considered as precedential video texts [5: pp. 64-66]. L. I. Gaidai's, successful Soviet film director, comic science fiction film Ivan Vasilievich Changes Profession (1973), staged the play by Mikhail Bulgakov, is what one is to regard as a film-intertext. It was one of the most attended movies in the Soviet Union in 1973 with more than 60 million tickets sold.

Precedential film-intertexts, including the aforementioned one, are intrinsically interwoven with precedential expressions (PEs), precedential situations (PSs), and precedential names (PNs). This relationship is two-folded: on the one hand, in such film-intertexts a significant number of PEs, PSs, and PNs that are already present in the language prevails; on the other hand, the phrases and names in a film become precedents after it appears on television. Hence, precedential become the following quotations from Ivan Vasilievich Changes Profession: "меня терзают смутные сомнения", “я артист Больших и Мальх театров”, “икра заморская баклажанная", "сесть я всегда успею" and many others. Since it sometimes becomes difficult under the conditions of natural communication to adequately understand the speech of the Russians without knowing most commonly used PEs, a substantial number of PEs in the given film-intertext turns the film itself into a valuable teaching aid. One is, moreover, to discern different types of PEs:

Rendering only a superficial meaning:

Милославский: Граждане, храните деньги в сберегательной кассе!

Иван Грозный: Жалую тебе шубу с иарского плеча!

Conveying both profound and surficial meanings:

Бунша: ...Если хотите знать, нам, иарям, за вредность надо молоко бесплатно давать! Surficial knowledge in the example provided above is easily understood on the basis of a sum of the definitions of words constituting PEs, whereas a deep/connotative meaning - "the tsar's work that is equated to the work in hazardous employment wherein working people would receive free milk" - is not always perceived by a foreign learner.

- Having practically no superficial meaning:

Милиционер: Тамбовский волк тебе боярин!

In addition, PEs can be divided into canonical expressions realized through a rigorous quotation that is non-motivated (not subject to any changes), for example: "Не вели казнить!" "Царь всея Руси" and transformative ones which can be 
modified within the text, though easily identifiable and recoverable, for example: “живьём брать демонов" or Zina's remark "я бросаю мужа, этого святого человека со всеми удобствами" (compare: "a sacred person" and "an apartment with all the conveniences").

The film-intertext under examination is also characterized by the presence of PSs which can be both verbal and visual, furnished with no words. Striking examples of different PSs are related to an episode where Shurik is searching for a rare part for his time machine (a non-verbal PS) and his dialogue with Uliana Andreevna (a verbal PS):

Ульяна Андреевна: “Александр Сергеевич! Однуминуточку! Передайте Зинаиде Михайловне, что Розалия Франиевна говорила Анне Ивановне, Капитолина Андреевна дублёнку предлагает. Так что, если...

Шурик: Я ничего не могу передать Зинаиде Михайловне: она уехала."

Precedential film-intertexts comprise PNs as well. First, PNs occur where they are associated with other precedential texts or the situation which is wellknown to a native speaker, either with a historical event or prominent figures in the sphere of politics, arts, and literature. For instance, in the above-mentioned film there are names such as Ivan Grozny, Miloslavsky, Sergei Bondarchuk, Innokenty Smoktunovsky, Juri Nikulin, but there are also names-symbols indicating a specific unity of certain qualities (Tarapunka and Shtepsel: "Тоже мне Tарапунька и Штепсель нашёлся!"). Second, the characters' names quite often become precedents (e.g., Shurik, the name of one of the main characters) [5: pp. 65-66].

Cinematography, as a source of cultural knowledge, in many cases is thrived on literary works. "When a screenplay is based on a literary work known to the speakers of Russian culture, the intersection of cultural domains obscures the 'etymology' of a cultural sign" [7: p. 64]. On the one hand, while appealing to a similar precedential text in the process of communication, it becomes difficult to figure out what acts can be ascribed to a precedential text - a book or a film, but on the other hand, considering native speakers' level of knowledge gained through abundant reading, one may maintain that it is the film that is to be treated as a source for reference and comparison. It is proved by multiple gaffes and discrepancies in terms of names of literary characters, details of the content, a setting where an event is described, and so forth, unless the author's idea of a literary text is fully rendered in a film. From this perspective, M. N. Krylova's example is rather compelling and confirming the above-mentioned hypothesis. Compare the words from the television series Thank You for Everything: "Меня по запаху крови волки найдут, примут в стаю, как Маугли. Буду в трусах по лесу бегать" to the literary work. It is known that only in The Adventures of Mowgli (1967-1971), an animated feature-length story film, does Mowgli run in the loincloth, while in the original R. Kipling's The Jungle Book (1894), the hero wears no clothes at all [7: p. 64].

L. I. Gaidai in his film did not seek to fully reproduce all the details of Bulgakov's play; he retained the author's intention and storyline. By extensively 
utilizing Bulgakov's unique language and humor, the director of the film fills the play with new realities corresponding to his contemporary slice of time. In this regard, an action from the communal apartment of the 1930s is transferred to a separate apartment in a new house of the 1970s; instead of "foreign materials" being difficult to obtain in the 1930s, we have a sheepskin coat being hardly obtainable but stylish and desired by any fashionista in the 1970s; the time machine itself does not correspond to the description in the play - rather, it represents, from a technical point of view, a more complex system congruous with a technological thought of that time when the film was being created; a gramophone is replaced by a cassette recorder; thief Miloslavsky appears not in a stolen suit but in Shpak's suede jacket being hardly available in the 1970s. Moreover, in the film Shpak becomes a dentist (a prestigious, well-paid specialty in the 1970s) but not a servant.

Some Bulgakov's scenes and dialogues are not included in the film at all. For example, an episode in which Bunsha, reacting painfully to being called "prince" by Timofeev, explains to him his own non-noble lineage. Bunsha in Bulgakov's play worries about a timely payment of apartments by residents, while in the film he is concerned about the disappearance of electricity because of the engineer's experiments. However, both in the play and in the film, for Bunsha, the time machine itself seems dangerous and suspicious and needs giving a report to "where one should". Accommodating the action in the play to a different time, into the plot L. I. Gaidai integrates a scene where Shurik searches for a necessary hardly available transistor (which has been burnt out) and purchases it from the speculator continuing Bulgakov's motive about the presence of deficit. Even the name of the protagonist is changed; that is, instead of engineer Nikolai Ivanovich Timofeev (his wife calls him Koki) there emerges engineer Alexander Sergeevich Timofeev (Shurik), a character that comes from two other "immortal" comedies by L. I. Gaidai and is still immensely popular in contemporary Russia like most Leonid Gaidai's movies from that era.

One can continue enumerating the director's reworkings. By retaining the whole plot, the idea, and the color of Bulgakov's work, the director brings the action closer to the contemporary, thereby making the film more attractive to the viewer. However, notwithstanding the director's admissible deformations of a source text, one can still say that a literary work is implicitly textured into the native speaker's cognitive domain through the film. This makes it possible to consider this film as a suitable teaching material for acquainting a foreign learner with M. A. Bulgakov's play and creative works. Furthermore, teachers have vast opportunities to apply complementary linguistic-cultural material combining information not only about the life in the Soviet Union in the 1970s but also about the time of Stalin's rule; to compare Bulgakov's and Gaidai's civil positions; to view this material through the lens of our time. The experience has shown that such an approach appeals to learners, encourages them to search for additional cultural information, elicits their interest to discuss what they have learnt and express their own opinion. 


\section{Research Work on the Script of Ivan Vasilievich Changes Profession}

The research work on the script of Ivan Vasilievich Changes Profession was constructed by drawing upon concrete objectives the teachers of the second foreign language had to realize in order to achieve the research aim:

1) Sustaining language discourse competence in the domains of phonetics, lexis, and grammar;

2) Sustaining language discourse skills in various types of speech activity, that is, communicative competence of the discourse: listening, speaking, reading, and writing;

3) Sustaining linguistic and cultural language discourse competence;

4) Sustaining language discourse of social and cultural competence; that is, understanding both the rules of verbal and non-verbal behavior in typical communicative situations and peculiarities of Russian native speakers' etiquette in in accordance to one's behavior;

5) Acquainting with M. A. Bulgakov's oeuvre and short literary analysis of his work.

From a culturological, linguoculturological, and linguistic-cultural point of view, Gaidai's film has an extraordinary illustrative character that stimulates learners not only to understand a verbal text accompanying an "image" but also perceive a cultural-historical background wherein the characters of the film live and act. The presence of two slices of time - that is, the epoch of Ivan the Terrible and the Soviet period of the 1970s, an astonishing mixture of their styles and morality elicit an acute comic effect [2: p. 134] but also allow teachers to acquaint learners with the Russian history.

During the lesson, there emerges the need to characterize the author's creative works and his personality referring to the text of Bulgakov's play itself and explaining why it had not been staged in theatres for a long time. It should be noted that morality in Bulgakov's play is under the conditions of despotic authority any mediocracy which may lead the state, and its machinery will go on crushing people mercilessly with obvious and dangerous (applicable to I. V. Stalin) allusions that turned the play into an uncensored literary work. In addition, it is also worthwhile mentioning that before L. I. Gaidai screened Ivan Vasilievich, it had been known to a rather narrow circle of readers.

The teacher should explain that the play Ivan Vasilievich was written by M. A. Bulgakov in 1935-1936, and its events, referring to the Soviet period, correspond to the time when it was written. The main hilarious effect was that superintendent Bunsha, a drunkard, voluptuary, dummy, and real snitch, turns out to be quite capable of acting as a powerful Ivan the Terrible, while the oprichnina's creator is absolutely helpless in the role of the Soviet superintendent of the house [2: pp. 136-137]. In this regard, it is expedient to get learners familiar with the tsar's personality and the historical epoch being described. This comedy film may 
create students' misconceptions about Ivan the Terrible as a historical personality. Therefore, when presenting to the students the epoch of Ivan the Terrible, it is necessary to emphasize that for all his unbridled cruelty (he sanctioned and led the massacre of Novgorod; the persecution of family boyars and church; the murder of Metropolitan Philip; the murder of his own son and heir Ivan), Tsar Ivan IV was an educated man and talented political figure. Relying upon officious noblemen and landowners, Ivan the Terrible tried in every possible way to strengthen his power through the reform of a central and local government (1549-1560) [1: pp. 144146]. As supplementary teaching aids, you can also use texts on Russian history, fragments from the film Tsar by Pavel Lungin, where the image of Ivan IV is shown from other perspectives (Jatautaite, Kazimianec, 2018).

\section{Conclusions}

A wide spectrum of film scripts that people with different cultural backgrounds are immersed entail inexhaustible methodological possibilities for foreign language teachers. Hence, developing film-intertexts in sustaining the discourse, herein, in the Russian language course or any other foreign language taught for foreign learners. It is necessary to optimize the teaching process in general, making it more appealing to learners, and thus bringing a learning environment closer to real life. Comprehending what is new is becoming less difficult for a bigger part of discourse information. It is also easier for the learner to comprehend and learn from, for example, television screen - what is common for a new generation learner. Moreover, screen versions of literary works are represented as a valuable culturological resource and can serve as a means of familiarizing the learner not only with history, culture, customs, and in this case mentality of the Russian people but also with a literary work itself, the author's oeuvre.

Cinematography or film-related materials and their presentation in class is a time-consuming process that requires teachers to possess extensive professional knowledge and outstanding creative capabilities. An appropriate choice of a film, suitable as authentic teaching material, is the key to a successful teaching and sustaining social linguistic discourse during the second language learning process overall. Collecting linguistic data for developing novel discourse based on a screen version of a literature work should be verified with the learners in class so that to meet all the requirements for authentic teaching resources. In addition, a film-intertext should, also undoubtedly, constitute a precedential text. In terms of methodical development of the discourse, it is necessary to take into account a unique nature of a film-intertext; to draw upon the knowledge of both discourse theory and the theory of speech activity; to attract supplementary resources by expanding a cultural and informative horizon of the lesson; and to creatively approach the development of tasks making them original and adequate for teaching objectives. 


\section{The Results and Recommendations of the Research}

There is a number of requirements and recommendations which have been obtained after the implementation of both audiovisual and film-related materials into the research. The latter is to be watched during the second foreign (Russian) language classes and is, in fact, as follows:

1. Film-related materials should incorporate necessary lexical, grammatical, and phonetic data sufficient within the framework of learning objectives.

2. A film should represent a precedential text. In other words, it should be known to the vast majority of native speakers and contain precedent situations, expressions, and names inasmuch as it is exactly the precedential texts that constitute the backbone of background information and are the basics of education at any level of learning process.

3. Taking into consideration an urgent issue of creating a cognitive basis essential for communication in a foreign language and common to a native speaker, the presence of a certain culturological background in the storyline or film-related materials as a fundamental criterion should be preserved.

4. A storyline should be compelling and correspond to the learner's needs and age and the level of his/her ability to practically use the language, which he/she attains and is able to understand.

5. Film-related materials should possess structural completeness (a definite composition wherein one can discern the beginning, middle, and end).

6. If video materials have the nature of a video clip, its content should directly be associated with the main subject of the lesson. The lesson is bound to include lexis congruent with its topic, thematically conditioned grammatical material and communicative situations characteristic of the presented topic.

7. The content of video materials should stimulate learners' discourse on what they have watched, search for additional information on the given topic and enable them to produce analogous dialogues with the use of acquired lexical and grammatical units in communicative language games.

8. Since teaching objectives invite learners to watch a video plot repetitively or multiple times, video materials should be multifaceted and incorporated besides diverse linguistic, paralinguistic and culturological resources [4: pp. 194-195].

9. Video materials used for educational purposes should be realized at a high level of cinematography [6: p. 69]. Among video texts - viewed herein as authentic teaching resources - a special emphasis is placed upon feature film-intertexts which, being specifically refracted in the characters' speech, should demonstrate an absolutely natural speech in a complete range of types and genres. "It is essential to find talented artistic realization enabling one to make it clear what the 'truth of life' is" [3: p. 27].

10. Video materials should be in unison with the requirements of moral values and aesthetic considerations. 
11. Films are means of bringing language immersion into the second foreign language learning classroom. Therefore, this didactic approach of screen versions of literary works is a valid and viable solution for the integration of film and television series into sustaining foreign language discourse.

12. Screen version of literary works in language teaching approach is very much a hands-on experience and requires a lot of attention on the part of the teacher who is supposed to facilitate between the video support and the students. At the same time, the teacher needs to ensure that the majority of the class is following in terms of comprehension. The teacher should be able to shift between the participants of the language process to accommodate the learner's needs and proficiency levels.

13. Screen versions of literary works provide a perfect setting for learners to venture into social, cultural and historic world of the studied language and learn the language in a virtual and real-life environment setting. Since the learner's engagement is a priority for a teacher in sustaining discourse of the second foreign language, it should proceed in pleasure as the learners are taught the pleasure of learning.

14. Sustaining social discourse through screen versions of literary works has become a central topic in the public sphere and a key concept in social change which has become an inevitable part of teaching the second foreign language.

\section{References}

1. Аверьянова Г.А. (2006). История России в зеркале русского языка. Книга для чтения (продвинутый этап) / Г.А. Аверьянова. - 2-е изд., доп. и испр. - М.: "Русский язык". Курсы, 2006.- 336 с.

2. Бабичева Ю.В. (1988). Фантастическая диалогия М. Булгакова. (“Блаженство" и “Иван Васильевич”) / Ю.В. Бабичева // М.А. Булгаковдраматург и художественная культура его времени / Сост. и ред. А.А. Нинов, В.В. Гудкова. - М.: Союз театральных деятелей РСФСР, 1988. - С.125 - 139.

3. Beck U. (1992). Risk Society: Towards a New Modernity. Trans. Mark Ritter. London, SAGE.

4. Bolinger D. (1989). Intonation and Its Uses: Melody in Grammar and Discourse. Stanford, California: Stanford University Press.

5. Bourdon M. (2006). De l'utilisation du cinéma en anglais de spécialité Carrières juridiques. Les Cahiers de l'APLIUT, vol. XXV, $n^{\circ}$ 1: 108-111. DOI: 10.4000/apliut. 2629.

6. Гончар И. А. (2011). Звучащий текст как объект методики в аспекте РКИ / И. А. Гончар // Русский язык за рубежом. - 2011.- N 2. - С.25-31.

7. Казимянец Е. Г. (2011). К вопросу об использовании киноматериалов на занятиях по РКИ в рамках диалога культур / Е.Г. Казимянец //Язык и межкультурные коммуникации. 
8. Материалы III. (2011). Международной научной конференции МинскВильнюс, 17-20 мая 2011 г. - Минск: БГПУ, 2011. - С.194-195.

9. Казимянец Е. (2006). О подготовке студентов к межкультурной коммуникации / Е. Казимянец //Žmogus ir Žodis. Научные труды. Вильнюсский педагогический университет.- 2006. - N 8(3). - С. 63 - 67.

10. Казимянец Е. (2010). Реализация принципа интерактивности в учебной книге по аудиовизуальному курсу русского языка / Е. Казимянец // Žmogus ir Žodis. Научные труды. Вильнюсский педагогический университет. N 12(3). - C.67 - 72.

11. Крылова М. Н. (2009). Художественный текст как прецедентный феномен / М.Н Крылова // Русская словесность. - 2009. - N 1. - С. 62-65.

12. McDonough J., Shaw, C. (1993). Materials and Methods in Elt: A Teacher's Guide. Oxford, UK: Blackwell Print.

13. Meadows D. H., Meadows, D, Randers, J, Behrens, W III. (1972). The Limits to Growth: A Report for THE CLUB OF ROME's Project on the Predicament of Mankind. London: Potomac Associates.

14. Jatautaite D., Kazimianec J. (2018). The importance of sustaining secure ambience for cadets of the Military Academy of Lithuania via balancing emotions and perception in attaining accelerated second language learning and acquisition // Journal of Security and Sustainability Issues. Vilnius: Generolo Jono Žemaičio Lietuvos karo akademija. ISSN 2029-7017. eISSN 2029-7025. 2018, vol. 8, no. 2, p. 161-170. DOI: 10.9770/jssi.2018.8.2(4).

15. Jatautaite D., Kazimianec J. (2018). The second foreign language teaching at the Military Academy of Lithuania (on the basis of audiovisual method) = Antrosios užsienio kalbos mokymas Generolo Jono Žemaičio Lietuvos karo akademijoje //Šiuolaikinès visuomenès ugdymo veiksniai $=$ TheFactors of Education in Modern Society: scientific journal. Vilnius: Generolo Jono Žemaičio Lietuvos karo akademija. ISSN 2424-6131. eISSN 2424-614X. 2018, t. 3, p. 259-268. Prieiga per internetą: http://ka.lt/lt/mokslineveikla/leidiniai/siuolaikines-visuomenesugdymo-veiksniai /download.html?id=1074;pdf_id=61818.

16. Richards J. C., Rodgers, T. S. (2001). Approaches and methods in language teaching. Cambridge: Cambridge University Press. DOI: 10.1017/ CBO9780511667305.

17. Compact Oxford Dictionary, Thesaurus and Wordpower Guide (2001). Oxford University Press, New York.

18. Barad K. (2007). Meeting the Universe halfway: Quantum physics and entanglement of matter and meaning. London: Duke University Press.

19. Sociological Discourse Analysis: Methods and Logic. Forum: Qualitative Social Research. 10 (2). 2009-05-30.

20. Piazza R., Bednarek, M., Rossi, F. (2006). Telecinematic Discourse: Approaches to the Language of Films and Television Series. John Benjamins Publishing. 
21. Hajer M. A. (1995). The Politics of Environmental Discourse: Ecological Modernization and the Policy Process, Oxford University Press, New York, NY.

22. Conrad J. (2012): Soziale Diskurse über (grüne) Gentechnik, Nachhaltigkeit, Transitionmanagement: Entwicklungsmuster und Zielbildung. Projektbericht. Berlin.

23. Weingart P. (2002). Von der Hypothese zur Katastrophe. Der anthropogene Klimawandel im Diskurs zwischen Wissenschaft, Politik und Medien. Opladen: Leske + Budrich. 


\title{
SOCIALINIO DISKURSO TVARUMAS TAIKANT LITERATŪROS KŪRINIŲ EKRANIZACIJAS MOKANT ANTROSIOS UŽSIENIO KALBOS
}

\author{
Doc. dr. Dileta Jatautaitė, doc. dr. Jelena Kazimianec \\ Generolo Jono Žemaičio Lietuvos karo akademija
}

\section{Santrauka}

Straipsnyje analizuojama M. Bulgakovo pjesės „Ivanas Vasiljevičius“ ekranizacija kaip efektyvus užsienio kalbų mokymo metodas. Šiame straipsnyje šis metodas yra pritaikytas konkrečiai rusų kalbos mokymo atvejui. Šiuo tikslu buvo sukonstruotas ir atliktas tyrimas, kuris parode šio metodo taikymo efektyvumą mokant rusų kalbos Lietuvos karo akademijoje. Šis metodas buvo pasirinktas, nes ekranizuotos literatūros kūrinių versijos mokant kalbų yra vertinamos kaip būdas studentus supažindinti ne tik su rusų literatūros klasika, bet ir su rusų tautos kultūra bei tam tikro laikotarpio kalbos diskursu. Mokantis užsienio kalbos socialinis diskursas yra labai svarbus, nes jis atspindi rašytinès ir šnekamosios kalbos kultūrologinius aspektus per semantiką ir diskurso analizę. Šiuo konkrečiu tyrimo objektu straipsnio autoriai pasirinko sovietinio režisieriaus L. Gaidajaus mokslo populiarinimo komediją „Ivanas Vasiljevičius keičia profesiją“ ir šio filmo interteksto atvejus, kurie yra laikomi precedentiniais vaizdo tekstais. Straipsnyje nagrinejami ir lyginami skirtingų laikotarpių socialinio diskurso kalbiniai, istoriniai ir kultūriniai šaltiniai. Siekdami intensyviai ir efektyviai mokyti studentus užsienio kalbos, autoriai pabrèžia nagrinèjamo originalaus teksto ir jo ekranizacijos pasirinkimo svarbą, nes ne visi tekstai tinka mokymui ir ne kiekvienas kūrinys gali būti tinkamas perteikti socialiniam diskursui, kuris suprantamas kaip precedentinis tekstas tos kalbos atstovui. Socialinio diskurso tvarumas vaidina neginčijamai reikšmingą vaidmenį originalios kalbos visuomenèje, o jo poveikis ir genezė yra savitas socialinių mokslų tyrimų objektas, siekiant originalų diskursą pritaikyti kalbų mokymosi erdvèje, kuri tampa ypatingu diskursu bendruomenès, kurioje dėstytojai ir studentai idealiu atveju yra reflektuojantys tikslinès kalbos istorinès raidos tyrejai. Socialinio diskurso tvarumas, naudojant ekranizuotas literatūros kūrinių versijas, tapo dominuojančiu metodu mokant užsienio kalbų, nes jis puikiai atspindi socialinės kalbos pokyčius, vykstančius viešojoje erdvèje.

Reikšminiai žodžiai: ekranizacija, M. Bulgakov, filmo intertekstas, užsieninis, kultūriniai ir kalbiniai resursai. 


\section{AUTORIŲ LYDRAŠTIS}

Autoriaus vardas, pavardè: Dileta Jatautaitè

Mokslo laipsnis ir vardas: socialinių mokslų daktarè, docentė

Darbo vieta ir pareigos: Generolo Jono Žemaičio Lietuvos karo akademijos Humanitarinių mokslų katedros docentė

Autoriaus mokslinių interesų sritys: psicholingvistika, glotoedukologija, edukologija, tradiciniai ir netradiciniai kalbų mokymo metodai bei metodologija, psichoedukologiniai kalbų mokymo bei išmokimo pagrindai

Telefonas ir el. pašto adresas: (8 5) 210 3560; dileta.jatautaite@mil.lt

Autoriaus vardas, pavardè: Jelena Kazimianec

Mokslo laipsnis ir vardas: humanitarinių mokslų daktarè, docentė

Darbo vieta ir pareigos: Generolo Jono Žemaičio Lietuvos karo akademijos Humanitarinių mokslų katedros docentè

Autoriaus mokslinių interesų sritys: dabartinė rusų kalba, rusų kalbos gramatika, lingvokultūrologija, svetimujų kalbų dėstymo didaktika, sociolingvistika, komparatyvistinè lingvistika

Telefonas ir el. pašto adresas: + 37068759 272; jelena.kazimianec@lka.lt

\section{AUTHORS' COVER LETTER}

Author's name and surname: Dileta Jatautaitè

Academic degree and name: Associate Professor, Doctor

Workplace and position: General Jonas Žemaitis Military Academy of Lithuania, Department of Humanitarian Sciences

Author's research interests: psycholinguistics, glotoeducology, neurolinguistics, traditional and non-traditional language teaching methods and methodology, psycho-educational basis in language learning and acquisition.

Telephone and e-mail address: +370 5210 3560; dileta.jatautaite@mil.lt

Author's name and surname: Jelena Kazimianec

Academic degree and name: Associate Professor, Doctor

Workplace and position: General Jonas Žemaitis Military Academy of Lithuania, Department of Humanitarian Sciences 